Bull. Mater. Sci., Vol. 36, No. 4, August 2013, pp. 755-764. (C) Indian Academy of Sciences.

\title{
Effect of calcination conditions of pork bone sludge on behaviour of hydroxyapatite in simulated body fluid
}

\author{
AGNIESZKA SOBCZAK-KUPIEC**, ZBIGNIEW WZOREK, REGINA KIJKOWSKA ${ }^{\dagger}$ \\ and ZYGMUNT KOWALSKI \\ Institute of Inorganic Chemistry and Technology, Cracow University of Technology, Warszawska 24, \\ 31-155 Kraków, Poland \\ ${ }^{\dagger}$ The Alfred Meissner Higher School of Dental Engineering and Humanities, Sloneczna 2, 43-450 Ustron, Poland
}

MS received 24 June 2011; revised 19 April 2012

\begin{abstract}
The paper presents in vitro (in SBF) behaviour of hydroxyapatite (HAp) obtained from pork bone sludge from meat plant via two essentially different calcination methods using a stationary, electrically heated chamber oven and enlarged laboratory scale rotary kiln designed by the authors, heated by gas combustion methods enabling application of different set of physical parameters such as temperature, holding time-differing according to type of the kiln. HAp ceramic discs, after 62-days of incubation in SBF at $37^{\circ} \mathrm{C}$, characterized by $\mathrm{X}$-ray diffraction (XRD), FTIR, SEM and EDS methods, underwent changes recorded by: (i) a reduction in Ca/P molar ratio in all the investigated materials resulting from modification in phase composition and (ii) weight increase in the investigated disc-samples, resulting from a precipitation of newly formed phase as an admixture of primary $\mathrm{HPO}_{4}^{2-}$-free $\mathrm{HAp}^{-}$ They were: secondary (with $\mathrm{HPO}_{4}^{2-}$ incorporated) $\mathrm{HAp}$ and chlorapatite in all the samples, while in addition to the listed above, $\beta$-tricalcium phosphate was formed on the discs made of HAp from stationary chamber oven, but not from rotary kiln. The new phases were formed in agglomerates on the surface of the investigated ceramic discs and in their pores. The results obtained proved that calcination conditions of pork bone sludge (temperature $750-950{ }^{\circ} \mathrm{C}$, time and type of the applied kiln) under which hydroxyapatite (HAp) powders were obtained had an impact on its different behaviour in SBF, nevertheless, indicating a potential ability of the material to form a new biologically relevant interface with hard tissue and suitability for further investigations intended for medical grafting.
\end{abstract}

Keywords. Natural hydroxyapatite; simulated body fluid; incubation; biomaterial; pH changes; rotary calcining kiln; chamber oven.

\section{Introduction}

The subject of developing new biologically relevant materials useful for dentistry and skeletal tissue reconstruction on surgically operated patients have received a great deal of attention. Most of the materials are based on synthetic hydroxyapatite (HAp) and related calcium phosphates (Jarcho 1981; De Groot 1983; Hulbert 1990; Nishihara and Akagawa 1990; LeGeros 1991; Święciki 1992; KnychalskaKarwan and Ślósarczyk 1994; LeGeros et al 1995a,b; Knychalska-Karwan et al 1998; Ducheyne and Qiu 1999; Benhayoune et al 2000; Orlovskii et al 2002; Li et al 2002; Raynaud et al 2002; Pena and Vallet-Regi 2003; Hing 2004; Hsu et al 2005; Li et al 2007; Sopyan et al 2007; Fathi et al 2008; Daculsi et al 2008; Brandt et al 2008; Salms et al 2009; Funayama et al 2009). Synthetic HAp-calcium phosphate of chemical and crystallographic similarity with mineral component of natural bone have an ability to form strong chemical bonds with the living hard tissue (Jarcho 1981; Nishihara and Akagawa 1990; Knychalska-Karwan et al 1998; Ducheyne and Qiu 1999; Benhayoune et al 2000; Fathi

\footnotetext{
*Author for correspondence (asobczak@chemia.pk.edu.pl)
}

et al 2008; Salms et al 2009; Funayama et al 2009). In bonetissue engineering, porous HAp ceramics have found enormous use in biomedical applications including bone tissue regeneration, cell proliferation and drug delivery. It has been applied as a filler of bone defects, as a material for bone augmentation in prosthesis revision surgery and as a coating on implants such as total hip replacement (THR).

Synthetic hydroxyapatite with molar ratio of $\mathrm{Ca} / \mathrm{P}=1.67$ with a corresponding stoichiometry of $\mathrm{Ca}_{10}\left(\mathrm{PO}_{4}\right)_{6}(\mathrm{OH})_{2}$ can be obtained hydrothermally above $300{ }^{\circ} \mathrm{C}$ or by solid-state reaction at temperatures above $900{ }^{\circ} \mathrm{C}$ (Kay et al 1964; LeGeros 1991). Stoichiometric hydroxyapatite is characterized by a monoclinic crystal structure (Kay et al 1964; LeGeros 1991). Synthetic hydroxyapatite precipitated from water solutions at room temperature and higher or by hydrolysis of acidic calcium phosphates is always nonstoichiometric, Ca-deficient, (def-HAp) is characterized by a molar ratio of $\mathrm{Ca} / \mathrm{P}$ lower than 1.67 (Berry 1967; Posner et al 1984). The variation of $\mathrm{Ca} / \mathrm{P}$ molar ratio is caused mostly by substitution of $\mathrm{HPO}_{4}^{2-}$ for phosphate $\mathrm{PO}_{4}^{3-}$ ion, while hydroxyapatite is formed in water solution (Posner et al 1980, 1984; LeGeros 1991). Synthetic-nonstoichiometric as well as biological apatites, constituents of bones and teeth are 
characterized by hexagonal crystal structure (LeGeros 1974, 1991; Posner et al 1980, 1984).

In hydroxyapatite structure, $\mathrm{PO}_{4}^{3-}$ anions can be partially substituted with carbonate group-type $\mathrm{B}$ of carbonated hydroxyapatite - as opposed to type A of high-temperature carbonated hydroxyapatite, in which hydroxyl groups are partially substituted with $\mathrm{CO}_{3}^{2-}$ (LeGeros et al 1968, 1971; Suetsugu et al 1997; Rajabi-Zamani et al 2008). Substitutions in anionic sublattice with other chemical elements such as chlorine or fluorine are common (LeGeros 1991; LeGeros et al 2006). Calcium partially substituted with magnesium $(0.7 \mathrm{wt} \%)$, sodium (0.9 wt $\%)$, potassium $(0.03 \mathrm{wt} \%)$ and microelements such as $\mathrm{Sr}, \mathrm{Pb}, \mathrm{Zn}, \mathrm{Cu}$ and $\mathrm{Fe}$ have also been found (LeGeros et al 1989; 1995a, b; Veiderma et al 2005; Kalita and Bhatt 2007). The non-stoichiometry, particularly Ca-deficiency, as well as the presence of foreign ions, affect properties of hydroxyapatite such as reduction in crystal size (crystallinity), increase in solubility related to resorbability if the material has been implanted in human system, thermal stability is essential for elaboration of HAp based materials for further medical purpose, etc (Jarcho 1976; LeGeros 1991; Raynaud et al 1998, 2002; De Champos and Bressiani 2002; LeGeros et al 2006).

Fabrication of hydroxyapatite ceramics usually involves precipitation from water solution and subsequent sintering at temperatures higher than $1000{ }^{\circ} \mathrm{C}$ (Jarcho 1976; De Groot 1983; Raynaud et al 1998; De Champos and Bressiani 2002; Li et al 2002).

Before a precipitated Ca-deficient hydroxyapatite undergoes sintering and densification at temperatures above $1000{ }^{\circ} \mathrm{C}$, several complex processes occur at lower temperature (Liao et al 1999; Gibson et al 2000; Wang and DornerReisel 2004; Mostafa 2005; Shih et al 2006): (i) water adsorbed on the surface is released below $200{ }^{\circ} \mathrm{C}$, (ii) temperature range of $300-500{ }^{\circ} \mathrm{C}, \mathrm{HPO}_{4}^{2-}$ decomposition occurs according to reaction:

$$
2 \mathrm{HPO}_{4}^{2-} \rightarrow \mathrm{P}_{2} \mathrm{O}_{7}^{4-}+\mathrm{H}_{2} \mathrm{O},
$$

with a release of water proceeds and (iii) above $700{ }^{\circ} \mathrm{C}$, partial dehydroxylation of hydroxyapatite is caused by the reaction:

$$
\begin{aligned}
& 2 \mathrm{Ca}^{2+}+\mathrm{P}_{2} \mathrm{O}_{7}^{4-}+\mathrm{Ca}_{10}\left(\mathrm{PO}_{4}\right)_{6}(\mathrm{OH})_{2} \\
& \quad \rightarrow 4 \beta-\mathrm{Ca}_{3}\left(\mathrm{PO}_{4}\right)_{2}+\mathrm{H}_{2} \mathrm{O} .
\end{aligned}
$$

At temperature higher than $1000{ }^{\circ} \mathrm{C}$ HAp gradually releases $\mathrm{OH}^{-}$ions (Shih et al 2006). Sintering temperature higher than $1300{ }^{\circ} \mathrm{C}$ cause transformation:

$$
\beta-\mathrm{Ca}_{3}\left(\mathrm{PO}_{4}\right)_{2} \rightarrow \alpha-\mathrm{Ca}_{3}\left(\mathrm{PO}_{4}\right)_{2},
$$

and formation of tetracalcium phosphate (TTCP) = $\mathrm{Ca}_{4}\left(\mathrm{PO}_{4}\right)_{2} \mathrm{O}$. If carbonate or foreign ions are incorporated into synthetic hydroxyapatite, thermal decomposition and transformation processes may be more (not less) complex. Thus, physicochemical properties (phase composition, specific surface area, density and mechanical properties) of the sintered hydroxyapatite ceramics depend on the initial hydroxyapatite structure formed and the temperature of thermal treatment.

While synthetic HAp materials have been used widely in medical applications, attention has been focused recently on HAp preparation methods from animal bones supplied by slaughter-houses. It is believed that HAp from natural sources, after proper physicochemical treatment and thermal processing, can be regarded as an attractive material for further investigations intended for medical grafting (Rosen et al 2002; Murugan et al 2003; Goller et al 2006; Haberko et al 2006; Ooi et al 2007; Barakat et al 2009; Sobczak et al 2009, 2010a,b; Younesi et al 2010). The macroporosity of hydroxyapatite obtained from bovine bone is conserved to a greater or lesser extent, depending on the temperature of heat treatment, however, crystallinity of bone apatite is changing with temperature increase.

The ability of a material to form new bone on its surface (bioactivity), can be determined by in vitro experiments while the material is incubated in simulated body fluid (SBF). In the literature concerning hydroxyapatite, it has been claimed that the behaviour of the hydroxyapatite upon immersion in SBF depends on structure and composition of the material associated to some extent with a dissolution ability (Radin and Ducheyne 1993; Ducheyne et al 1993; Milev et al 2003). The hydroxyapatite dissolution rate is dependent mainly to the crystallinity level, phase composition, microstructure, surface area and density, etc (LeGeros 1991; Ducheyne et al 1993; LeGeros et al 1995a,b; Milev et al 2003). Some in vitro and in vivo investigations concerning nano-HA confirmed that $\mathrm{Ca}^{2+}$ ion releases from the synthetic hydroxyapatite powders are similar to bone apatite, however, significantly faster than microcrystalline HA (Murugan and Ramakrishna 2004; Mohammadi et al 2008).

Summing up, voluminous literature concerning hydroxyapatite biomaterials, selectively cited in the present paper, refers mostly to synthetic materials. Our research has been focused on biological properties of hydroxyapatite of natural origin obtained with the use of a process elaborated in our institute and described elsewhere (Sobczak et al 2009, 2010a,b; Sobczak-Kupiec and Wzorek 2012).

In the present work, hydroxyapatite was obtained from pork bone (called bone sludge) through two routes of calcining: (i) with the use of a typical laboratory stationary chamber oven and (ii) an enlarged laboratory scale rotary kiln heated by gas combustion. The rotary kiln (figure 1) used for calcining, was constructed at our request. The kiln tube was made of heat-resisting steel. Internal wall of the rotary kiln was covered with chamote ceramics. The bone sludge for calcining was fed into rotary kiln at the rate of $100 \mathrm{~g} \cdot \mathrm{min}^{-1}$ concurrently with heating gas through a bucket (5) connected to a belt conveyor. Retention time of the material calcined in the kiln depends on rpm. Using $0.5 \mathrm{rpm}$, retention time was $40 \mathrm{~min}$. The parameters for calcining were selected after some preliminary tests, including temperature calibration in the kiln. The temperature of the wall measured at the outlet of the tube was treated as a calcining temperature. 
The present paper presents in vitro behaviour of hydroxyapatite obtained via two different methods with different set of physical parameters used for pork bone calcination in a stationary chamber or in a rotary kiln. In contrast to calcinations in the stationary chamber, the rotary kiln enabled agitation of the material calcined. The study aimed to investigate the influence of calcination parameters (temperature, holding time-differing according to type of the kiln) on the effects obtained after immersion of hydroxyapatite in simulated body fluid.

\section{Experimental}

\subsection{Hydroxyapatite preparation}

Deproteinized and defatted-bone pulp, received from meat plant, called bone sludge, was applied as a starting material in the present experiment. Bone sludge is a byproduct forming in a bone deproteinization process.

(i) The first step of the process (preliminary calcining) was carried out at a temperature of $650{ }^{\circ} \mathrm{C}$ in chamber oven or in rotary kiln (figure 1). Calcining time in chamber oven was $3 \mathrm{~h}$, while in the rotary kiln it was $40 \mathrm{~min}$.

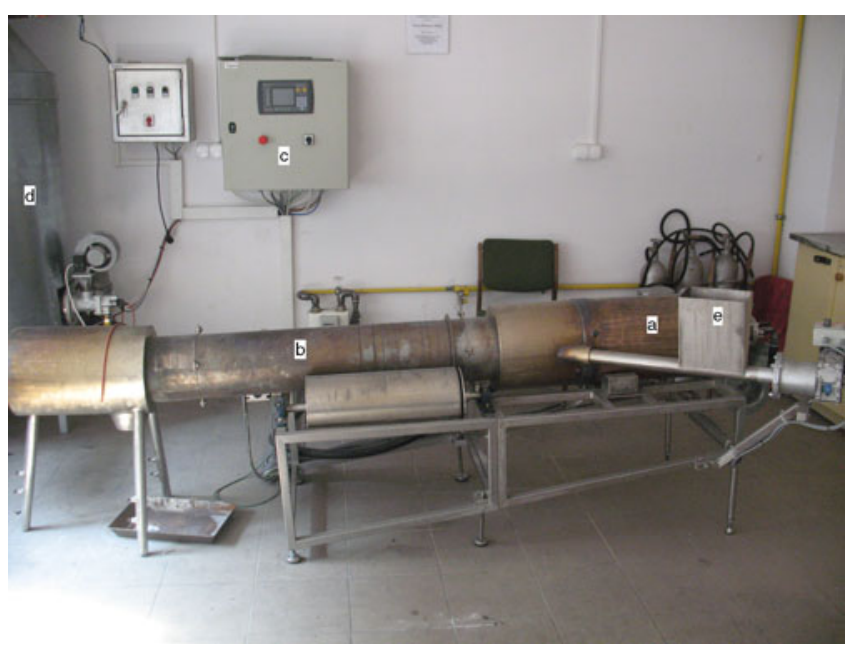

Figure 1. Picture of an experimentally enlarged laboratory scale rotary kiln. (a) Gas heater; (b) rotary heating tube of $1120 \mathrm{~mm}$ in length and $150 \mathrm{~mm}$ in diameter; (c) electronic controlling device; (d) after-burning chamber and (e) belt conveyor bucket. (ii) In the second stage of the process:

(a) The material preliminarily calcined at $650{ }^{\circ} \mathrm{C}$ in the stationary chamber oven was re-calcined in the same chamber oven with electric heating at temperatures 750 , 850 and $950{ }^{\circ} \mathrm{C}$ in air atmosphere for different times (2, 2.5 and $3 \mathrm{~h}$ ).

(b) The material preliminarily calcined in the rotary kiln was re-calcined at three temperature measurements: 750 , 850 and $950{ }^{\circ} \mathrm{C}$ recorded at the outlet of the rotary kiln with gaseous heating.

\subsection{Assessment of in vitro bioactivity}

Discs of a $13 \mathrm{~mm}$ diameter and weight amounting to $1.1 \mathrm{~g}$ of HAp powders obtained in the chamber $(\mathrm{CH})$ as well as in the rotary (ROT) kiln were made by the uniaxial compaction without a binder in a steel mould at a pressure of $74 \mathrm{MPa}$. The compacts were heated with the rate of $10 \mathrm{deg} \cdot \mathrm{min}^{-1}$ up to $950{ }^{\circ} \mathrm{C}$ and sintered in air for $3 \mathrm{~h}$.

The assessment of in vitro bioactivity was carried out in a solution of simulated body fluid (SBF) prepared according to Kokubo and Takadama (2006). SBF solution was related to a composition and concentration similar to that of human plasma. The immersion study was carried out at $37{ }^{\circ} \mathrm{C}$ by soaking the discs suspended vertically in a plastic container with $40 \mathrm{~mL}$ of SBF. The ion concentration of SBF (mmol) is given in table 1.

The ratio of the surface of the ceramic disc to SBF volume was $0.075 \mathrm{~cm}^{-1}$. The time of soaking was 62 days. The solution was freshened up every $24 \mathrm{~h}$ for 7 days and then once a week. After the immersion time was completed, the discs were removed from the solution, washed with distilled water, dried at $105{ }^{\circ} \mathrm{C}$ and analysed. The solution $\mathrm{pH}$ was analysed and adjusted using the $\mathrm{pH}$-meter (Elmetron) with a combined electrode (Elmetron). The result was a mean of three measurements.

\subsection{Methods of phase analysis}

The phase composition of the samples was analysed by X-ray diffraction method with the use of Philips X'Pert diffractometer equipped with a graphite monochromator PW 1752/00, CuK $\alpha 1.54 \mathrm{~nm}$, Ni filter (40 kV, $30 \mathrm{~mA})$.

Table 1. Comparison of ion concentration and $\mathrm{pH}$ value of SBF and human plasma (Kokubo and Takadama 2006).

\begin{tabular}{|c|c|c|c|c|c|c|c|c|c|}
\hline & \multicolumn{8}{|c|}{ Ion concentration $\left(\mathrm{mmol} / \mathrm{dm}^{3}\right)$} & \multirow[b]{2}{*}{$\mathrm{pH}$} \\
\hline & $\mathrm{Na}^{+}$ & $\mathrm{K}^{+}$ & $\mathrm{Mg}^{2+}$ & $\mathrm{Ca}^{2+}$ & $\mathrm{Cl}^{-}$ & $\mathrm{HCO}_{3}^{2-}$ & $\mathrm{HPO}_{4}^{2-}$ & $\mathrm{SO}_{4}^{2-}$ & \\
\hline Human plasma & $142 \cdot 0$ & $5 \cdot 0$ & $1 \cdot 5$ & $3 \cdot 5$ & $103 \cdot 0$ & $27 \cdot 0$ & $1 \cdot 0$ & $0 \cdot 5$ & $7 \cdot 2-7 \cdot 4$ \\
\hline SBF & $142 \cdot 0$ & $5 \cdot 0$ & $1 \cdot 5$ & $3 \cdot 5$ & $147 \cdot 8$ & $4 \cdot 2$ & $1 \cdot 0$ & $0 \cdot 5$ & $7 \cdot 4$ \\
\hline
\end{tabular}


FT-IR infrared analyses, within the basic infrared range of $400-4000 \mathrm{~cm}^{-1}$, were conducted with the use of Scimitar Series FTS 2000 spectrophotometer produced by the Digilab Co. The sample of $0.0007 \mathrm{~g}$ was pressed with $0 \cdot 2000 \pm 0 \cdot 0011 \mathrm{~g} \mathrm{KBr}$ into a pellet.

The molar ratio of $\mathrm{Ca} / \mathrm{P}$ (before and after incubation) was determined by chemical analyses of HAp samples. Calcium was analysed by complexometry (EDTA in the presence of calcein and thymolphthalein as the indicator), while phosphorus as a $\mathrm{P}-\mathrm{Mo}-\mathrm{V}$ complex by colorimetry (Marcel Media).

The morphology and particle size of HA was observed by SEM-EDS, Hitachi.

\section{Results and discussion}

\subsection{Characteristics of samples before soaking in SBF}

Identification of powder diffraction patterns of the investigated samples was based on JCPDS-ICCD materials database. The $d$-spacing (related to angle of diffraction) and relative intensities of diffraction peaks observed corresponded to hydroxyapatite crystal structure (card JCPDS no. 9-432), while no other phase in the samples obtained was found. Typical XRD diffraction patterns of the two samples are presented in figure 2 . All the samples obtained in stationary chamber as well as in rotary kiln exhibited (similar to figure 2) XRD patterns indicating hydroxyapatite hexagonal crystal structure.

FT-IR spectra (figure 3) demonstrate differences in crystal structure in relation to thermal treatment of the bone sludge. Spectrum (figure 3(a)) of non-thermally-treated bone sludge is typical of low crystallinity 'apatitic', as well as an amorphous phosphate (LeGeros et al 1973; LeGeros 1991). It is characterized by 'loss of resolution in the characteristic $\mathrm{PO}_{4}^{3-}$

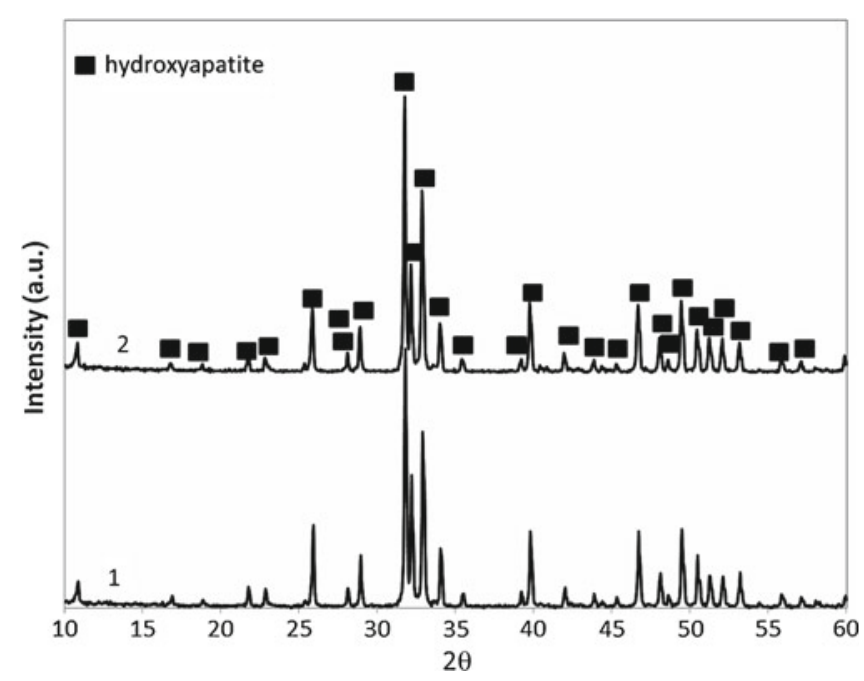

Figure 2. X-ray diffraction patterns of hydroxyapatite obtained by calcining bone sludge; $2 \mathrm{~h}$ in stationary chamber oven at $950{ }^{\circ} \mathrm{C}$ and $40 \mathrm{~min}$ in rotary kiln at $950{ }^{\circ} \mathrm{C}$. bands (vibration modes $v 3$ an $v 4$ ) which are normally degenerate in the IR absorption spectra of apatites' (LeGeros et al 1973; Fowler et al 1966). Absorption bands in the region of around $1400-1600 \mathrm{~cm}^{-1}$ wavenumber are showing the presence of carbonate group $\left(\mathrm{CO}_{3}^{2-}\right)$ and organic compound.

FT-IR spectrum (figure 3(b)), pre-ignited at $650{ }^{\circ} \mathrm{C}$ bone is typical of hydroxyapatite crystal structure characterized by $\mathrm{OH}$ group bands at wavenumber of $\sim 610 \mathrm{~cm}^{-1}$ and $\sim 3600 \mathrm{~cm}^{-1}$ (LeGeros et al 1973; LeGeros 1991). Absorption band at a wavenumber of $\sim 960 \mathrm{~cm}^{-1}$ has been assigned to $v_{1}$-symmetric $\mathrm{P}-\mathrm{O}$ stretching mode, at $1000-1100 \mathrm{~cm}^{-1}$ to $v_{3}$-asymmetrical stretching mode of $\mathrm{P}-\mathrm{O}$, while absorption bands recorded within the wavenumber range of 570$630 \mathrm{~cm}^{-1}$ were assigned to $v_{4}$-asymmetrical deformation of $\mathrm{O}-\mathrm{P}-\mathrm{O}$ vibrational mode in tetrahedral $\mathrm{PO}_{4}^{3-}$ ion. Thermal pre-treatment at $650{ }^{\circ} \mathrm{C}$ caused organic component burning out, elimination of most carbonate, while initial bone mineral component transformed into crystalline hydroxyapatite form.
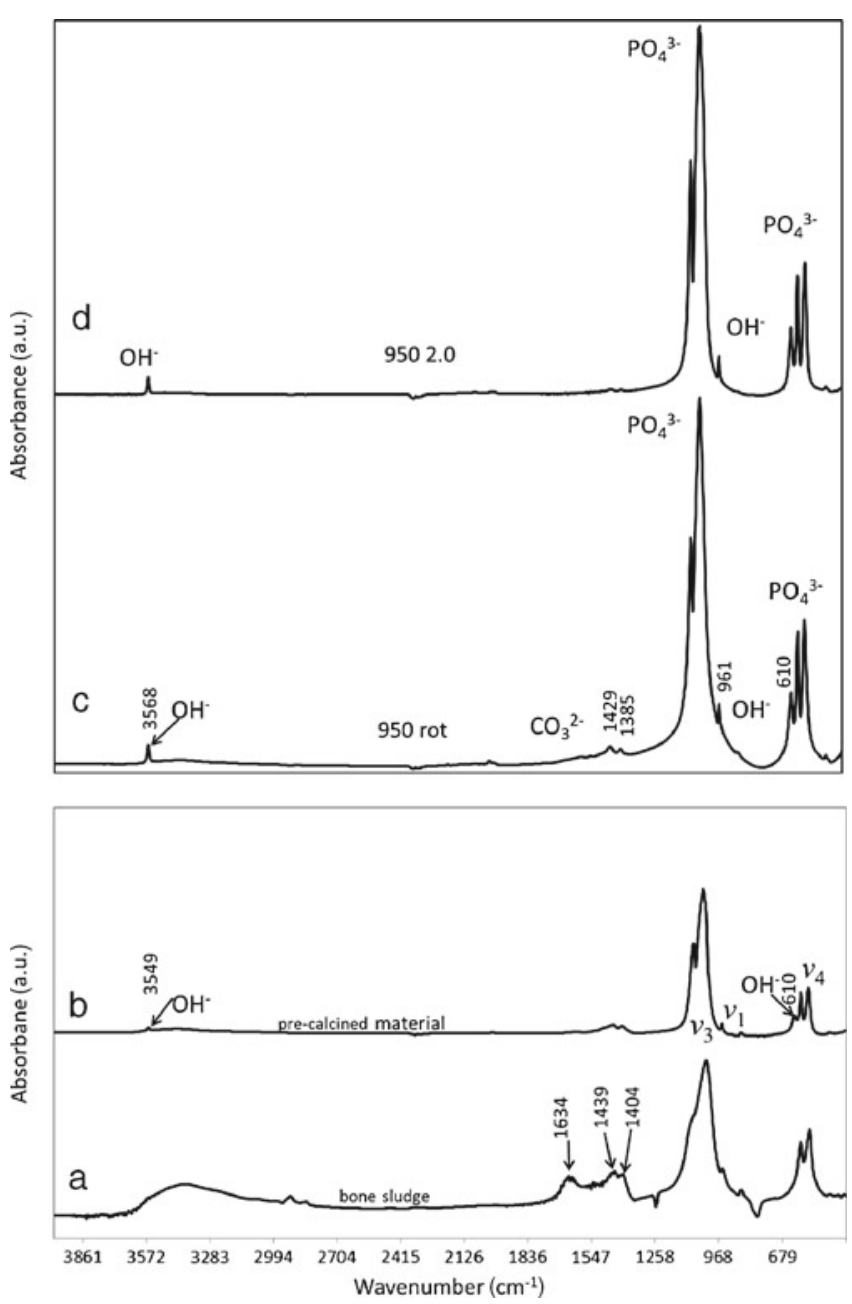

Figure 3. FT-IR spectra of hydroxyapatite obtained by calcining of bone sludge: (a) as prepared, not calcined, (b) pre-calcined at $650{ }^{\circ} \mathrm{C}$, (c) re-calcined at $950{ }^{\circ} \mathrm{C}$ in stationary chamber for $2 \mathrm{~h}$ and (d) re-calcined in rotary kiln $\left(950^{\circ} \mathrm{C}, 40 \mathrm{~min}\right)$. 
FT-IR spectra (figure 3(c and d)) of the samples calcined at higher than $650{ }^{\circ} \mathrm{C}$ are characteristic of highly crystalline (high resolution of the bands) hydroxyapatite according to LeGeros et al (1973) and LeGeros (1991). However, spectra of the samples obtained in rotary kiln contained weak bands of $\mathrm{CO}_{3}^{2-}$ indicated in figure 3(c). The presence of some small amount of carbonate in the hydroxyapatite may have resulted from the presence of $\mathrm{CO}_{2}$ in gaseous atmosphere in the rotary kiln heated by gas combustion.

\subsection{Results obtained in SBF}

Chemical stability and biological activity were evaluated on the basis of $\mathrm{pH}$ changes recorded with time of immersion in simulated body fluid (SBF) - relevant to natural human environment (figure 4).

When ceramic discs made of HAp produced in the chamber oven $(\mathrm{CH})$ were incubated in simulated body fluid, an increase in $\mathrm{pH}$ value in the initial period of time was observed. During the first two days, the $\mathrm{pH}$ value of SBF reached the maximum and amounted to 7.67 and 7.81 for $\mathrm{HA}$ at 850 and $950{ }^{\circ} \mathrm{C}$, respectively. On the third day of soaking, the $\mathrm{pH}$ value decreased to a level of $\sim 7.50$. During the next
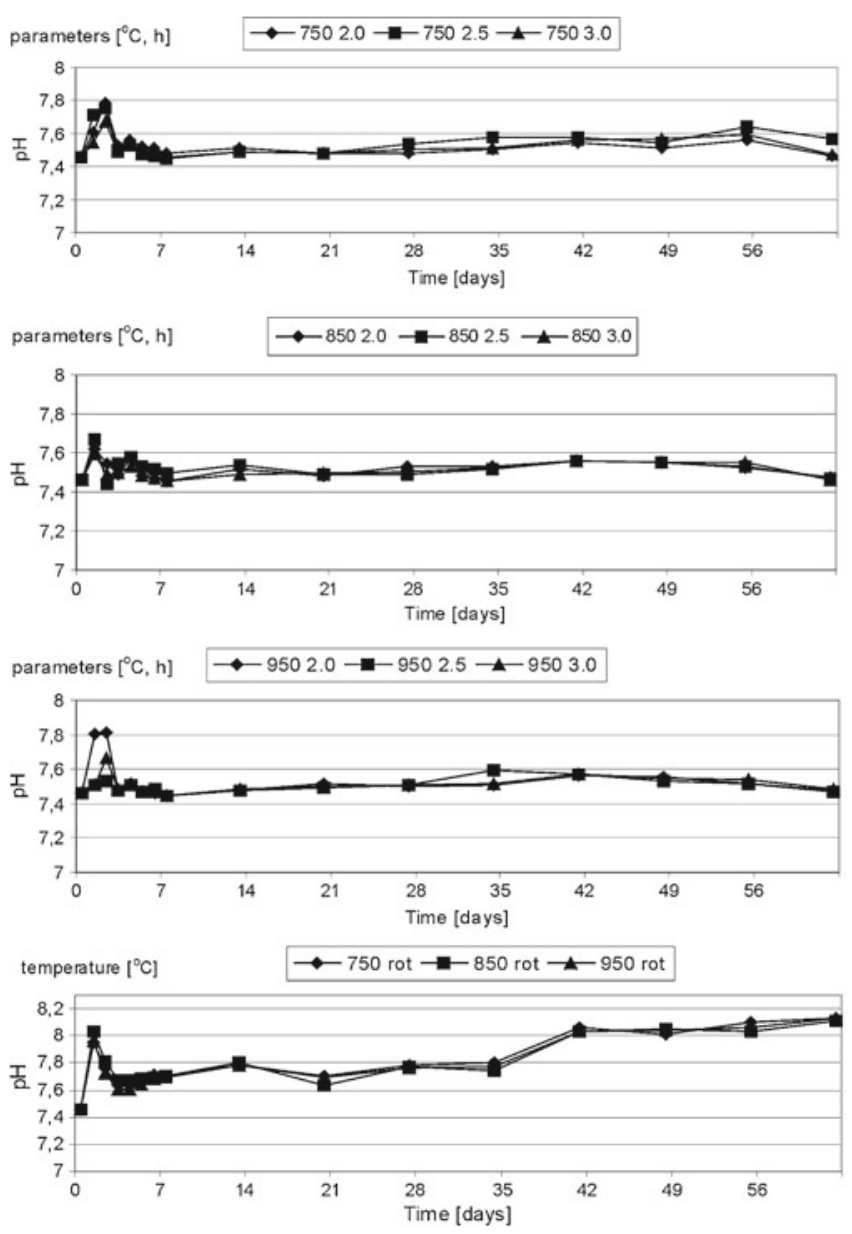

Figure 4. $\mathrm{pH}$ changes of simulated body fluid in course of HAp incubation.
24 days, the $\mathrm{pH}$ value was varying insignificantly, however, a negligible tendency towards lower $\mathrm{pH}$ values at the end of incubation time was observed. The differences between $\mathrm{pH}$ of SBF in which HAp samples obtained from chamber oven at different temperatures: 750, 850 and $950{ }^{\circ} \mathrm{C}$ were not significant. It was also confirmed that the calcining time did not influence $\mathrm{pH}$ value of the SBF. In contrast, the samples made of HAp obtained in the rotary kiln (ROT) exhibited not only a distinct growth in $\mathrm{pH}$ value of SBF up to 8.03 (after $24 \mathrm{~h}$ ) with a subsequent decrease and stabilization in the following days, a $\mathrm{pH}$ increase was also observed at the end of the immersion time and reached the final value amounting to 8.13 (figure 4 ). The behaviour of all HAp (ROT) discs in SBF was similar to each other and the calcining temperature exerted no significant influence on the environmental SBF $\mathrm{pH}$. The observed $\mathrm{pH}$ increase in the initial period of immersion time with subsequent $\mathrm{pH}$ decrease in all the investigated samples may suggest that dissolution and precipitation processes in SBF were likely to occur (figure 4) (Raynaud et al 2002; Kim et al 2008). According to Kim et al (2008), two stages (dissolution/precipitation) in apatite formation are possibly occurring. Also, Ruixue et al (2006) reported initial $\mathrm{Ca}$-concentration increase and subsequent decrease recorded with time of soaking in SBF. Thus, it can be presumed that at first stage of incubation some dissolution at the surface of HAp disc accompanied by $\mathrm{pH}$ increase in SBF leads to oversaturation, while in second stage, nucleation and re-precipitation of new hydroxyapatite proceeds.

The samples, after immersion in SBF, were collected, dried at a temperature of $105{ }^{\circ} \mathrm{C}$ to a constant weight and analysed. Figure 5 demonstrates that weight of all HAp discs increased during immersion time, suggesting continuous precipitation of a new solid. The most intensive weight increase was recorded in the discs made of $\mathrm{HA}$ calcined at $950{ }^{\circ} \mathrm{C}(\mathrm{CH})$, which after 62 days amounted to $\sim 3 \%$ (figure 5); whereas the weight growth to a level of $2.3 \%$ was recorded for the samples made of HAp $(\mathrm{CH})$ calcined at 750 and $850{ }^{\circ} \mathrm{C}$. The smaller weight increase (up to $1.6 \%$ ) was recorded in ceramic discs made of HAp obtained in the rotary

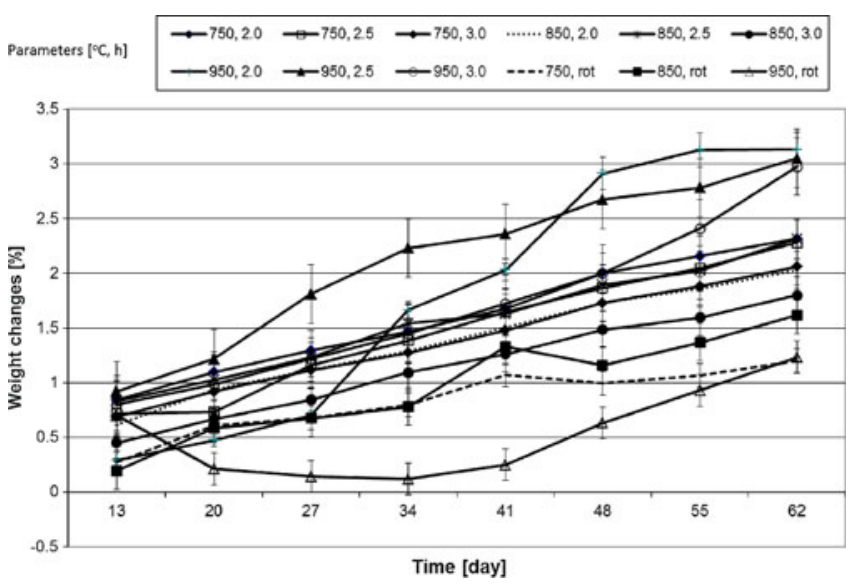

Figure 5. Weight changes of HAp samples as a function of immersion time in SBF. 
kiln. The general tendency towards weight increase during soaking in SBF can be related to a precipitation of calcium phosphate phases mainly on the surface and perhaps into the pores (Raynaud et al 2002; Medvecky et al 2006).

After chemical analysis, the content of calcium and phosphorus obtained were recalculated into $\mathrm{Ca} / \mathrm{P}$ molar ratio (figure 6).

In all the investigated ceramic solids (from chamber and rotary kiln), the $\mathrm{Ca} / \mathrm{P}$ molar ratio after in vitro test in simulated body fluid decreased in comparison with the $\mathrm{Ca} / \mathrm{P}$ molar ratio before immersion. $\mathrm{Ca} / \mathrm{P}$ molar ratio after immersion in SBF fluid was between 1.59 and 1.63. The observed $\mathrm{Ca} / \mathrm{P}$ decrease resulted from precipitation of a newly formed Ca-deficient hydroxyapatite as well as some small amounts of other phosphates. According to Raynaud et al (1998, 2002), superficially deposited layer of Ca-deficient HAp, having $\mathrm{HPO}_{4}^{-}$incorporated is as given below

$$
\left(\mathrm{H}^{+}+\mathrm{PO}_{4}^{3-}\right)_{\text {solution }} \rightarrow\left(\mathrm{HPO}_{4}^{2-}\right)_{\text {solid }} .
$$

Ca-deficiency coupled with $\mathrm{HPO}_{4}^{2-}$ incorporation has been known since 60th of XXst century when Berry (1967), later in 80th Posner et al $(1980,1984)$, LeGeros et al (1982) and LeGeros (1991) reported that HAp, precipitated from water solutions was Ca-deficient and contained internal hydrogen bonds between oxygen of adjacent orthophosphate groups, resulting in the presence of $\mathrm{HPO}_{4}^{2-}$, not observed in the stoichiometric hydroxyapatite. Since then $\mathrm{HPO}_{4}^{2-}$ ion has always been referred to as the absorption band in IR spectra in synthetic as well as in some biological apatites.

Figure 7 representing a typical FT-IR spectrum after discs were soaking in SBF, gave an evidence that HAp containing $\mathrm{HPO}_{4}^{2-}$ appeared. The band of $\mathrm{HPO}_{4}^{2-}$ was found at a wavenumber of $870 \mathrm{~cm}^{-1}$ which was in agreement with the literature values. It has to be noted that $\mathrm{HPO}_{4}^{2-}$ band was not present in HAp material before soaking in SBF (compare

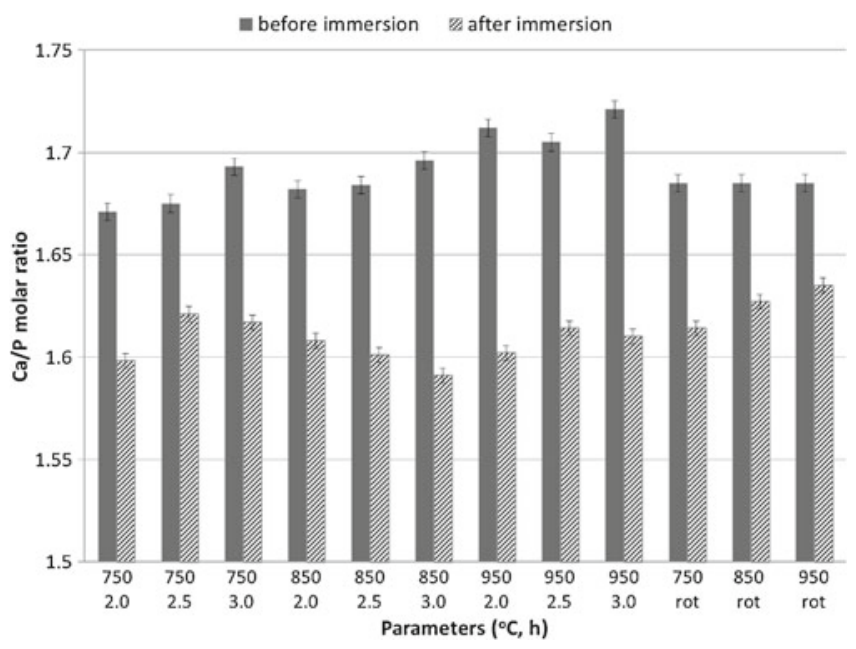

Figure 6. Comparison of $\mathrm{Ca} / \mathrm{P}$ molar ratio in $\mathrm{HA}$ samples before and after immersion in SBF. figure 7 with figure 3), because that was not precipitated from water solution. The rest of the spectrum in figure 7 , except the absence of weak bands of the $\mathrm{CO}_{3}^{2-}$ groups, was similar to those before the immersion in SBF in figure 3.

XRD analysis of ceramic samples after soaking in SBF indicates some modification in phase composition-the appearance of different additional phases in relation to chamber/rotary kiln as recorded in figure 8 . The main com-

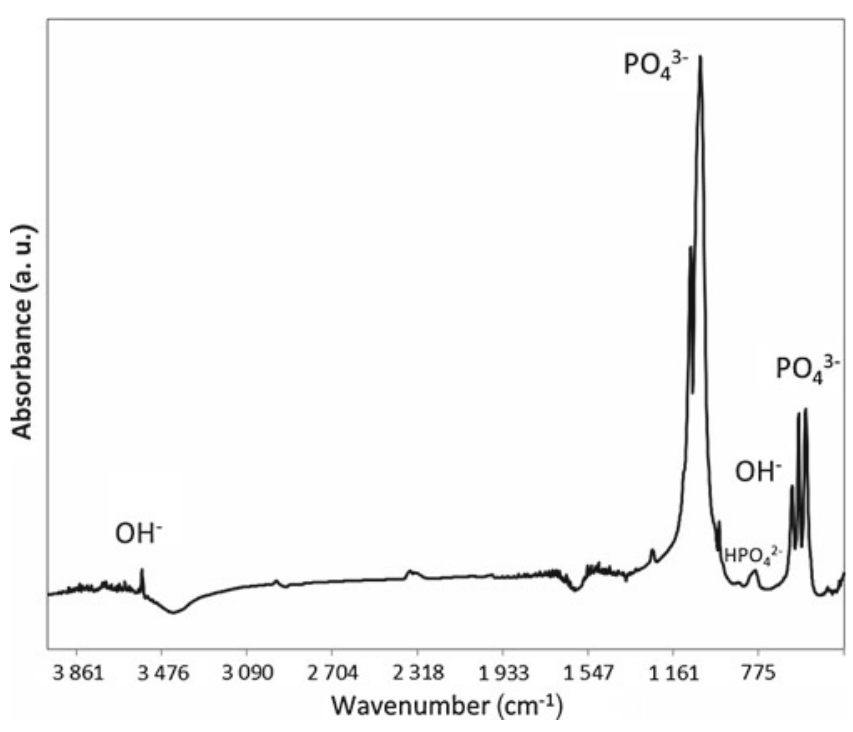

Figure 7. Representative FT-IR spectrum of HAp ceramics obtained under the following conditions: $950{ }^{\circ} \mathrm{C}, 2 \mathrm{~h}, \mathrm{CH}$, after immersion in simulated body fluid.

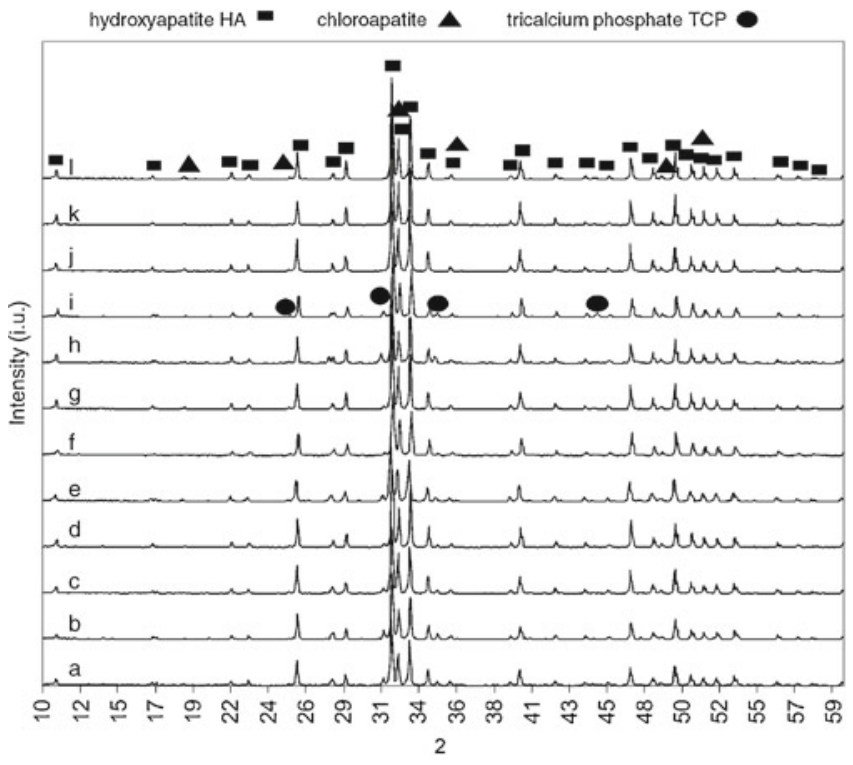

Figure 8. Diffractograms of HA ceramics after soaking in simulated body fluid. Calcination parameters of HA powders $\left({ }^{\circ} \mathrm{C}, \mathrm{h}\right.$, kiln): (a) 750, 2, CH, (b) 750, 2.50, CH, (c) 750, 3, CH, (d) 850, 2, $\mathrm{CH}$, (e) $850,2 \cdot 5, \mathrm{CH}$, (f) $850,3, \mathrm{CH}$, (g) 950, 2, CH, (h) 950, 2.5, CH, (i) 950, 3, CH, (j) 750, ROT, (k) 850, ROT and (l) 950, ROT. 
ponent is hydroxyapatite highlighted in the model X-ray spectrum in JCPDS 9-432. XRD peaks of low intensity according to JCPDS 33-271 corresponded to chlorapatite, $\mathrm{Ca}_{10}\left(\mathrm{PO}_{4}\right)_{6} \mathrm{Cl}_{2}$, appearing as an admixture in samples from both chamber and rotary kiln after SBF. In contrast, $\beta$ variety of tricalcium phosphate $(\beta-\mathrm{TCP})=\beta-\mathrm{Ca}_{3}\left(\mathrm{PO}_{4}\right)_{2}$ highlighted by JCPDS 09-0169 appeared only in the samples calcined in chamber oven.

The microstructural characteristics of the HAp samples after 62-day immersion in SBF investigated by scanning electron microscopy are shown in figure 9. The observations are similar to those found in literature, for example, in Kim et al (2008). The precipitation of new phases on the surface of HAp ceramics as well as in the micropores was observed in samples obtained in chamber and also in rotary kiln. The precipitation of calcium phosphate phases on the surface of HAp samples obtained in the stationary oven was the most visible. Small spherical outgrowths of calcium phosphate agglomerates are formed on the surface of
HA bioceramic. In the case of ceramic discs made of HAp from the rotary kiln, the precipitation was less intensive and smaller aggregates were formed.

EDS analysis was performed in the samples after 62-day immersion in SBF. In all the cases, a similar spectrum was obtained. Figure 10 shows a representative EDS spectrum of HAp $\left(950{ }^{\circ} \mathrm{C}, 2.5 \mathrm{~h}, \mathrm{CH}\right)$. The highest number of counts in EDS spectrum of HAp samples after immersion in SBF corresponded to calcium and phosphorus - the main components of hydroxyapatite. The counts referred to carbon, sodium and oxygen are located within the range of the lowest energy $0.25-0.5 \mathrm{keV}$. The peak at $2.7 \mathrm{keV}$ was assigned to chloride present in the chlorapatite structure.

Figure 11 presents the distribution of chemical elements on representative HAp sample surfaces after immersion in SBF. These images demonstrate a very good homogeneity of the analysed surfaces with one exception, the distribution of chlorine was not uniform. The distribution of chemical elements such as carbon, oxygen, phosphorus, calcium
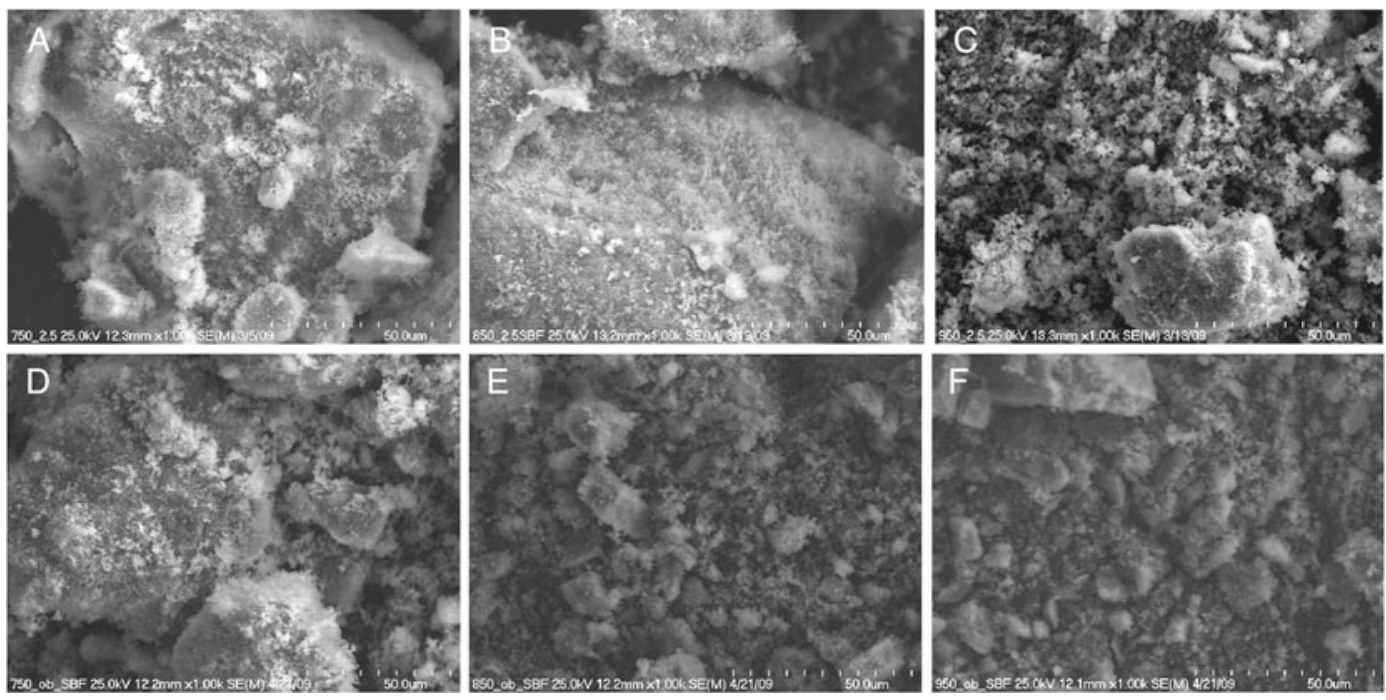

Figure 9. SEM micrograph $(1000 \times$ enlargement $)$ of HA samples after 62-day immersion in SBF obtained under following conditions (temperature/time/kiln): (A) $750{ }^{\circ} \mathrm{C}, 2 \cdot 5 \mathrm{~h}, \mathrm{CH},(\mathbf{B}) 850^{\circ} \mathrm{C}, 2 \cdot 5, \mathrm{CH},(\mathbf{C}) 950{ }^{\circ} \mathrm{C}$, $2.5 \mathrm{~h}, \mathrm{CH},(\mathbf{D}) 750^{\circ} \mathrm{C}$, ROT, (E) $850{ }^{\circ} \mathrm{C}$, ROT and (F) $950{ }^{\circ} \mathrm{C}$, ROT.

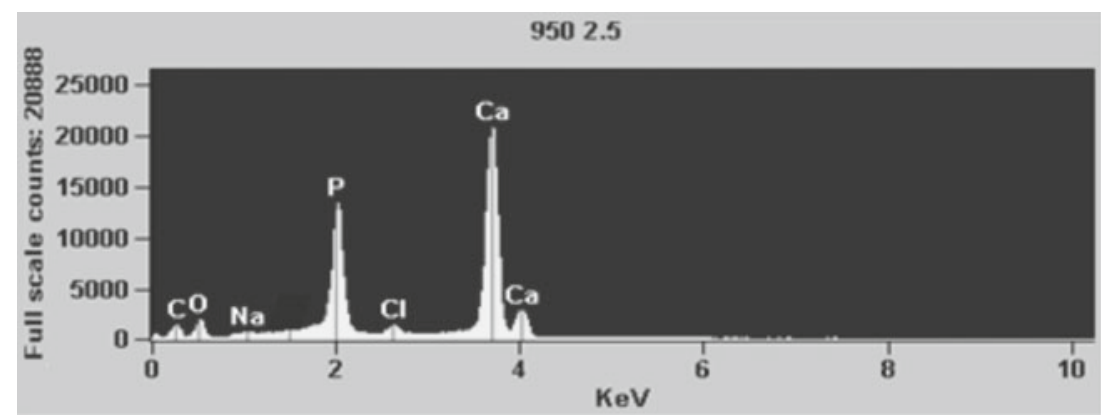

Figure 10. EDS spectrum of $\mathrm{HA}\left(950^{\circ} \mathrm{C}, 2 \cdot 5 \mathrm{~h}, \mathrm{CH}\right)$ after 62-day of immersion in $\mathrm{SBF}$ at $37^{\circ} \mathrm{C}$. 

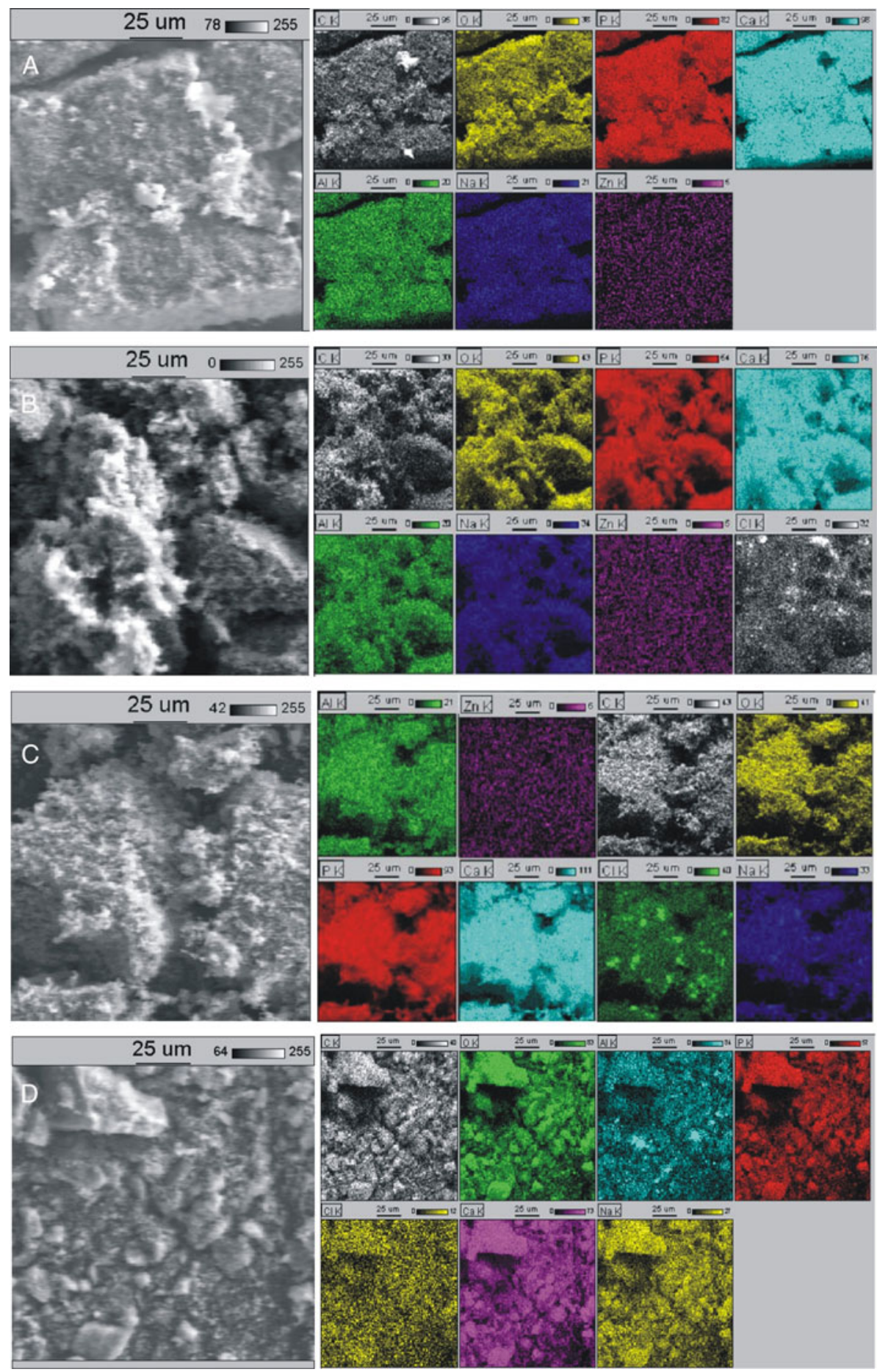

Figure 11. Distribution of chemical elements on HA surfaces after immersion in SBF. (A) $750{ }^{\circ} \mathrm{C}, 2.5 \mathrm{~h}, \mathrm{CH},(\mathbf{B}) 850{ }^{\circ} \mathrm{C}, 2.5 \mathrm{~h}, \mathrm{CH},(\mathbf{C}) 950{ }^{\circ} \mathrm{C}, 2.5 \mathrm{~h}, \mathrm{CH}$ and (D) $750{ }^{\circ} \mathrm{C}, 2.5 \mathrm{~h}, \mathrm{ROT}$.

and sodium in all the cases was almost uniform. The concentrations of these elements were located in an irregular manner on the surface of HAp samples, from both chamber and rotary kiln. A new chlorapatite phase was precipitated on the surface of HAp samples after immersion in simulated body fluid at $37^{\circ} \mathrm{C}$, however, this phase did not cover the whole surface.

\section{Conclusions}

In vitro (in $\mathrm{SBF}$ ) behaviour of hydroxyapatite (HAp) obtained from pork bone sludge from meat plant via two essentially different calcination methods using a stationary, electrically heated chamber oven, and designed by the authors enlarged laboratory scale rotary kiln, heated by gas 
combustion-methods enabling application of different set of physical parameters such as temperature, holding timediffering according to the type of the kiln can be summarized as below.

(I) HAp ceramic discs, after 62-day of incubation in SBF at $37{ }^{\circ} \mathrm{C}$, characterized by X-ray diffraction (XRD), FTIR, SEM and EDS methods, underwent changes recorded by: (a) a reduction in $\mathrm{Ca} / \mathrm{P}$ molar ratio in all the investigated materials resulting from modification in phase composition, (b) weight increase in the investigated disc samples, resulting from precipitation of newly formed phases, as an admixture of primary, $\mathrm{HPO}_{4}^{2-}$-free $\mathrm{HAp}$, (c) secondary (with $\mathrm{HPO}_{4}^{2-}$ incorporated) HAp and chlorapatite were formed on disc samples made of HAp calcined in chamber oven as well as in rotary kiln, (d) in addition to those listed in (c), $\beta$-tricalcium phosphate $(\beta$-TCP) was formed on the discs made of HAp from stationary chamber oven, but not from the rotary kiln and (e) the new phases were formed in agglomerates on the surface of the investigated ceramic discs and in their pores.

(II) The components of SBF as well as the constituents of primary hydroxyapatite (obtained in chamber oven or rotary kiln), possibly dissolving at the surface of the discs were the source of ions participating in phase composition modification after immersion in SBF. $\mathrm{pH}$ increase in the initial period of immersion time with subsequent $\mathrm{pH}$ decrease may suggest that dissolution and precipitation processes in SBF were likely to occur.

(III) The results obtained proved that calcination conditions of pork bone sludge (temperature $750-950{ }^{\circ} \mathrm{C}$, time and type of the applied kiln) under which hydroxyapatite (HAp) powders were obtained had an impact on their different behaviours in SBF, nevertheless, indicating a potential ability of the material to form a new biologically relevant interface with hard tissue and suitability for further investigations intended for medical grafting.

The biologically relevant nature of the newly formed SBF deposits, containing a secondary $\mathrm{HAp}$ with $\mathrm{HPO}_{4}^{2-}$ incorporated, as well as $\beta$-TCP formed was confirmed by FT-IR (figure 7) and XRD (figure 8) results.

\section{Acknowledgement}

The research was supported by the National Centre for Science, Poland.

\section{References}

Barakat N A M, Khil M S, Omran A M, Sheikh F A and Kim H Y 2009 J. Mat. Proc. Technol. 2093408

Benhayoune H, Jallot E, Laquerriere P, Balossier G, Bonhomme P and Frayssinet P 2000 Biomaterials 21235

Berry E E 1967 J. Inorg. Nucl. Chem. 29317

Brandt J, Henning S, Michler G, Schulz M and Bernstein A 2008 Key Engineering Materials, Trans Tech Publications 361-363 35
Daculsi G, Chappard D, Aguado E, Legeay G, Layrolle P and Weiss P 2008 Key Engineering Materials, Trans Tech Publications 36136327

De Champos M and Bressiani A H 2002 Key Engineering Materials, Trans Tech Publications 218-220 171

De Groot K (ed.) 1983 Bioceramics of calcium phosphates: Preparation and properties. In: Bioceramics of Calcium Phosphate (Boca Raton, FL: CRC Press) p. 100

Ducheyne P and Qiu Q 1999 Biomaterials 202287

Ducheyne P, Radin S and King L 1993 J. Biomed. Mater. Res. 27 25

Fathi M H, Hanifi A and Mortazavi V 2008 J. Mater. Process. Technol. 202536

Fowler B O, Moreno E C and Brown W E 1966 Arch. Oral Biol. 11 477

Funayama T, Sakane M, Watanabe A, Abe T, Iwasashi M, Suetsugu Y and Ochiai N 2009 Bioceramics 22765

Gibson R I, Rehman I, Best S M and Bonfield W 2000 J. Mater. Sci.: Mater. Med. 11533

Goller G, Oktar F N, Agathopoulos S, Tulyaganov D U, Ferreira J M F, Kayali E S and Peker I 2006 J. Sol-Gel Sci. Technol. 37111

Haberko K, Bucko M, Brzezinska-Miecznik J, Haberko M, Mozgawa W, Panz T, Pyda A and Zarebski J 2006 J. Eur. Ceram. Soc. 26537

Hing K A 2004 Philos. Trans. R. Soc. A: Math. Phys. Eng. Sci. 362 2821

Hsu Y H, Turner I G and Miles A W 2005 Key Engineering Materials, Trans Tech Publications 284-286 305

Hulbert S F 1990 Bioceramics 31

Jarcho M 1976 J. Mater. Sci. 112027

Jarcho M 1981 Clin. Orthop. Rel. Res. 157259

Kalita S J and Bhatt H A 2007 Mater. Sci. Eng. C27 837

Kay M I, Young R A and Posner A S 1964 Nature 2041050

Kim Y K, Seo D S and Lee J K 2008 Appl. Surf. Sci. 255589

Knychalska-Karwan Z and Ślósarczyk A 1994 Hydroksyapatyt w stomatologii, Krakmedia, Kraków (in Polish)

Knychalska-Karwan Z, Kaczmarczyk-Stachowska A, Ślósarczyk A, Sobierska E and Paszkiewicz Z 1998 Front. Med. Biol. Eng. 8239

Kokubo T and Takadama H 2006 Biomaterials 272907

LeGeros R Z 1974 Arch. Oral Biol. 2063

LeGeros R Z 1991 Calcium phosphates in oral biology and medicine. Monographs in Oral Science (ed.) M Myers (New York: Karger) vol. 15

LeGeros R Z, Trautz O R, LeGeros J P and Klein E 1968 Bull. Soc. Chim. France 1712

LeGeros R Z, LeGeros J P and Trautz O R 1971 Adv. X-Ray Anal. 1457

LeGeros R Z, Shirra M A, Miravite M A and LeGeros J P 1973 Amorphous calcium phosphates: Synthetic and biological. Coll. Int. C.N.R.S. No 230-Physico-Chemie et Crystallographie des Apatites D'Intérêret Biologique, Paris, CRNS, p. 105

LeGeros R Z, Quirolgico G and LeGeros J P 1982 J. Dent. Res. 61 232, abstr 486

LeGeros R Z, Daculsi G, Kijkowska R and Kerebel B 1989 The effect of magnesium on the formation of apatites and whitlockites. In: Magnesium in Health and Disease (eds) Y Itokawa and J Durlach (John Libbey \& Co Ltd.) p. 11

LeGeros R Z, LeGeros J P, Daculsi G and Kijkowska R 1995a Encyclopedic handbook of biomaterials and bioengineering, in Calcium phosphate biomaterials: Preparation, properties and 
biodegradation (Marcel Dekker Inc.) Part A, Ch. 43, Vol. 2, p. 1429

LeGeros R Z, Kijkowska R, Bautista C and LeGeros J P 1995b Connect. Tissue Res. 311

LeGeros R Z et al 2006 Key Engineering Materials, Trans Tech Publication 309-311 697

Li Y, Weng W and Tam K Ch 2007 Acta Biomater. 3251

Li S H, de Groot K and Layrolle P 2002 Key Engineering Materials, Trans Tech Publications 218-220 25

Liao C J, Lin F H, Chen K S and Sun J S 1999 Biomaterials 20 1807

Medvecky L, Stulajterova R, Parilak L, Trpcevska J, Durisin J and Barinov S M 2006 Colloid Surf. A: Physicochem. Eng. Asp. 281 221

Milev A, Kannangara G S K and Ben-Nissan B 2003 Mater. Lett. 57/13-14 1960

Mohammadi Z, Ziaei-Moayyed A A and Mesgar A S M 2008 Biomed. Mater. 3015006

Mostafa N Y 2005 Mater. Chem. Phys. 94333

Murugan R and Ramakrishna S 2004 Biomaterials 253073

Murugan R, Rao K P and Sampathkumar T S 2003 Bull. Mater. Sci. 26523

Nishihara K and Akagawa T 1990 Bioceramics 3255

Ooi C Y, Hamdi M and Ramesh S 2007 Ceram. Int. 331171

Orlovskii V P, Komlev V S and Barinov S M 2002 Inorg. Mater. 38 973

Pena J and Vallet-Regi M 2003 J. Eur. Ceram. Soc. 231687

Posner A S, Blumenthal N C and Betts F 1980 Formation and structure of chemically precipitated hydroxyapatite. 2nd Int. congress on phosphorus composition, Boston, Mass., (Paris: USA IMPHOS) pp. 25-39

Posner A S, Blumental N C and Betts F 1984 Chemistry and structure of precipitated hydroxyapatite. In: Phosphate Minerals (eds) J O Nriagu and P B Moore (Springer-Verlag) p. 330

Radin S R and Ducheyne P 1993 J. Biomed. Mater. Res. 2735

Rajabi-Zamani A H, Behnamghader A and Kazemzadeh A 2008 Mater. Sci. Eng. C28 1326
Raynaud S, Chamion E and Bernache-Assollant 1998 Bioceramics 11109

Raynaud S, Champion E, Lafon J P and Bernache-Assollant D 2002 Biomaterials 231081

Rosen V B, Hobbs L W and Spector M 2002 Biomaterials 23921

Ruixue S, Musen L, Yupeng L and Aijuan W 2006 Mater. Charact. $\mathbf{5 6 / 3} 250$

Salms G, Skagers A, Salma I, Locs J, Berzina-Cimdina L and Feldmane L 2009 Bioceramics 22141

Shih W J, Wang J W, Wang M C and Hon M H 2006 Mater. Sci. Eng. C26 1434

Ślósarczyk A 1997 Hydroxyapatite bioceramics. Biuletyn Ceramiczny nr 13 Ceramika 51, Polskie Towarzystwo Ceramiczne, Kraków (in Polish)

Sobczak A, Kowalski Z and Wzorek Z 2009 Acta Bioeng. Biomech. 11/4 23

Sobczak A, Dobrzański Z and Zygadlik K 2010a Przem. Chem. 89/8 1073

Sobczak A, Błyszczek E, Kowalski Z and Wzorek Z 2010b Bone sludge as a raw material in the production of hydroxyapatite for biomedical applications. Environmental Engineering III (London: Taylor \& Francis Group) p. 307

Sobczak-Kupiec A and Wzorek Z 2012 Ceram. Int. 38641

Sopyan M, Mel Ramesh S and Khalid K A 2007 Sci. Technol. Adv. Mater. 8116

Suetsugu Y, Shimoya I and Tanaka J 1997 Bioceramics 10249

Święciki Z 1992 Bioceramika dla ortopedii, Instytut Podstawowych Problemów Techniki PAN, Wyd. Spółdzielcze Sp. z.o.o., Warszwa (in Polish)

Veiderma M, Tonsuaadu K, Knubovets R and Peld M 2005 J. Organomet. Chem. 6902638

Wang T and Dorner-Reisel A 2004 Mater. Lett. 583025

Yang Z, Thian E S, Brooks R A, Rushton N, Best S M and Cameron R E 2008 Key Engineering Materials, Trans Tech Publications 361-363 459

Younesi M, Javadpour S and Bahrololoom 2010 J. Mater. Eng. Perform. 20/8 1484 